\title{
Proteus penneri Isolated from the Pus of a Patient with Epidural Abscess
}

\author{
Zhongxing LI, Xiuhua WANG, Zhanshui BIAN, Shumin LI, Heping ZHENG, \\ Baozhen ZHAO and Jingpo CHEN
}

Bacteriological Laboratory, The Second Affiliated Hospital, Hebei Medical College, Shijiazhuang, China

(Received: July 8, 1991)

(Accepted: September 10, 1991)

Key words: P. penneri, epidural abscess

\begin{abstract}
P. mirabilis and P. vulgaris are the two wellknown species in the genus Proteus. $P$. myxofaciens and $P$. penneri are recent additions to the genus. We isolated $P$. penneri from the pus of a patient with suppurative otitis media and an epidural abscess. The characteristics of the organism, including morphology, staining, physiology and biochemistry, were studied. Clinical microbiological laboratories should suspect $P$. penneri in the case of as Proteus strain that is negative for indole, salicin and esculin, but otherwise resembles $P$. vulgaris.

Proteus penneri, formerly known as Proteus vulgaris indole-negative or as Proteus vulgaris biogroup 1, was named by Hickman et al in 1932. Little information about human infection by this organism is available. In 1982, Hickman and co-workers studied 20 strain of $P$. penneri which were isolated from clinical specinmens (urine, stool, etc.) in the USA. However, its clinical significance, until recently, was unknown ${ }^{1)}$. We isolated a strain of $P$. penneri from the pus of a patient with suppurative otitis media and an epidural abscess on June 10 and 15, 1989. This paper concerns the problems encountered in identifying this organism and its clinical significance.
\end{abstract}

\section{Case Report}

A 17-year-old male was admitted to our hospital on June 10,1989, with a 2-week history of headache, high fever and occasional vomiting. The patient had taken antibiotics with some improvement in symptoms, but headache was not relieved. There was a rather ill-defined 8-year history of left suppurative otitis media with acute episodes as well as epidural abscess.

Examination: T. $37.5^{\circ} \mathrm{C}$, P. $84 / \mathrm{min}, \mathrm{R} .20 / \mathrm{min}, \mathrm{BP} .110 / 70 \mathrm{mmHg}$. The patient was well-developed and moderately well-nourished. The skin and sclera showed no xanthochromia. The lungs and heart were normal. The liver and spleen were not palpable. Neurological examination showed left incomplete facial paralysis. The left mastoid region was mildly swollen a purulent secretion was evident on the surface of the drum membrane. Diagnosis: suppurative otitis media with epidural abscess and otogenic meningitis.

Radical mastoidectomy was carried out on June 10,1989. $150 \mathrm{ml}$ of yellowish-geen putrid pus was drained from the epidural space. The pus was sent immediately for bacteriological examination and a second specimen of the purulent secretion was cultures on the fifth day after the operation. Both cultures grew $P$. penneri. Based on susceptibility testing, the patient was given co-trimoxazole and gentamicin and discharged after recovery.

別刷請求先：中国河北省石家庄市

河北医学院第二医院細菌室 李 仲興 
Fig. 1 Colonies of $P$. penneri on blood agar

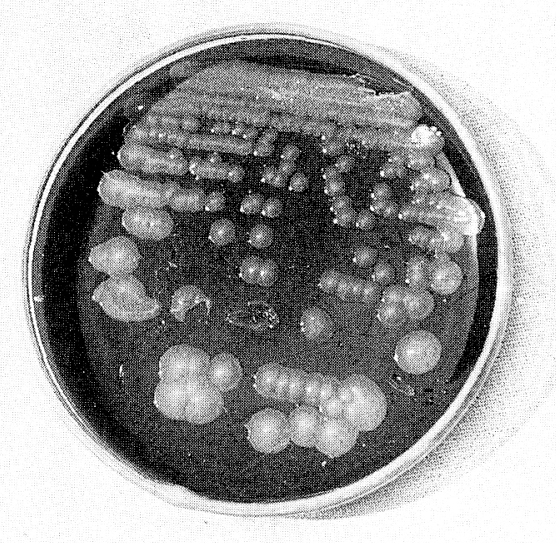

Fig. 2 Flagellum of $P$. penneri

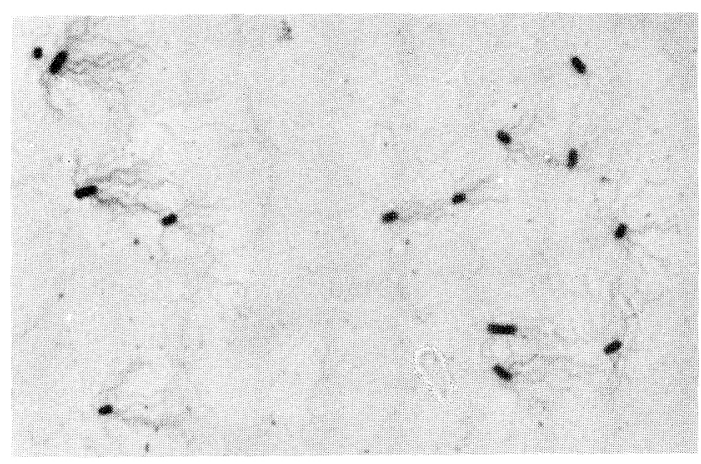

\section{Isolation and Identification}

The pus was inoculated directly on to blood agar according to standard methods. After 24 hours of incubation at $35^{\circ} \mathrm{C}$, it produced moderate $(2 \mathrm{~mm})$, convex, circular colonies with smooth adges (Fig. 1). Swarming appeared after the third generation of subculturing. Gram staining of the isolate revealed Gram-negative bacilli. Motillity was detarmined by direct microscopic examination of a wet mount and by a flagella stain, which showed active motile rods with peritrichous flagella (Fig. 2).

The isolate was oxide negative, and produced phenylalanine deaminase and urease. On Kligler agar, there was acidification of gloucose with a small bubble of gas, lactose was not present and a slant culture turned dark red, with blaking of the medium due to the abundant production of $\mathrm{H}_{2} \mathrm{~S}$. We assigned the isolate to the genus Proteus, and performed additional biochemical tests for further identification. The results were positive for ornithine, sucrose and maltose, but still did not permit unequivocal identification

Table 1 Characteristics differentiating three biogroups of $P$. vulgaris

\begin{tabular}{lccc} 
& Biogroup 1 & Biogroup 2 & Biogroup 3 \\
\hline Indole & - & + & + \\
Salicin & - & + & - \\
Esculin & - & + & - \\
\hline
\end{tabular}

Table 2 Differential characteristics of $P$. penneri and other Proteus ${ }^{4)}$

\begin{tabular}{|c|c|c|c|c|c|}
\hline & \multirow[b]{2}{*}{ 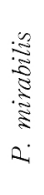 } & \multirow[b]{2}{*}{ 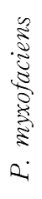 } & \multicolumn{3}{|c|}{ P. vulgaris } \\
\hline & & & 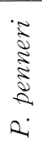 & $\begin{array}{l}N \\
0 \\
\Xi \\
0 \\
0 \\
0 \\
0 \\
0 \\
0\end{array}$ & $\begin{array}{c}m \\
\exists \\
0 \\
0 \\
0 \\
0 \\
0 \\
0\end{array}$ \\
\hline Indole production & - & - & - & + & + \\
\hline Ornithine decarboxylase & + & - & - & - & - \\
\hline Maltose fermentation & - & + & + & + & + \\
\hline Salicin fermentation & - & - & - & + & - \\
\hline D-Xylose fermentation & + & - & + & + & + \\
\hline Esculin hydrolysis & - & - & - & + & - \\
\hline $\begin{array}{l}\text { Occurs in human } \\
\text { clinical specimens }\end{array}$ & + & - & + & + & + \\
\hline $\begin{array}{l}\text { Occurs as pathogen } \\
\text { of gypsy moth larvae }\end{array}$ & - & + & - & - & - \\
\hline Chloramphenicol disk & $\mathrm{S}$ & $\mathrm{S}$ & $\mathrm{R}$ & V & $\mathrm{S}$ \\
\hline
\end{tabular}


Table 3 Biochemical reaction of $P$. penneri

\begin{tabular}{|c|c|c|c|}
\hline Test & Reaction & Test & Reaction \\
\hline Indole & - & Inositol & - \\
\hline MR & + & Lactose & - \\
\hline VP & - & Maltose & + \\
\hline Citrate (Simmons) & - & D-Mannitol & - \\
\hline $\mathrm{H}_{2} \mathrm{~S}$ & + & D-Mannose & - \\
\hline Urea & + & Melibiose & - \\
\hline Phenylalanine & + & Raffinose & - \\
\hline L-Lysine & - & L-Rhamnose & - \\
\hline L-Ornithine & - & Sorbitol & - \\
\hline L-Arginine & - & Salicin & - \\
\hline Motility & + & Sucrose & + \\
\hline Gelatin & + & Trehalose & + \\
\hline $\mathrm{KCN}$ & + & Xylose & + \\
\hline Malonate & - & Esculin & - \\
\hline \multirow[t]{2}{*}{ Glucose : } & + & Mucate & - \\
\hline & + & Acetate & - \\
\hline Acid from: & & $\mathrm{NO}_{3}-\mathrm{NO}_{2}$ & + \\
\hline Adonitol & - & DNase $\left(25^{\circ} \mathrm{C}\right)$ & + \\
\hline Arabinose & - & $35^{\circ} \mathrm{C}$ & + \\
\hline D-Arabitol & - & Oxidase & - \\
\hline Cellobiose & - & ONPG & - \\
\hline Dulcitol & - & Swarming on blood agar & + \\
\hline Galactose & + & $\mathrm{C}+\mathrm{O}$ content of DNA & $38.3 \mathrm{~mol} \%$ \\
\hline Glycerol & + & & \\
\hline
\end{tabular}

of the isolate as either $P$. vulgaris or $P$. mirabilis. We suspected that this organism represented a new species of Proteus.

In Bergey's Manual of Systematic Bacteriology (Vol. 1 1984), the genus Proteus includes three species, $P$. vulgaris, $P$. mirabilis and $P$. myxofaciens. The latter, which does not produce $\mathrm{H}_{2} \mathrm{~S}$, has not been isolated from human clinical specimens. ${ }^{2,3)}$.

Hickman et al studied DNA hybridization of $P$. vulgaris and found three biogroups within the species, one of which was indole-, salicin- and esculin-negative. They indicated that this group probably represented a new species of Proteus and referred to it as P. vulgaris biogroup 1. Differentiation among the 3 biogroups shown in Table 1. Our isolate was similar to $P$. vulgaris biogroup 1. P. penneri sp. nov was proposed as the name for this biogroup by Hickman in 1982.

We performed a series of biochemical tests, listed in Table 2, to further identify the present isolate. The results showed that this strain and $P$. penneri had identical characters. In view of the original isolation of this organism in China, we performed further biochemical tests and confirmed the isolate as P. penneri (Table 3).

Antibiotic susceptibility was tested by the Kirby-Bauer disk method, showing that this organism was susceptible to gentamicin, co-trimoxazole and kanamycin, intermediate to carbenicillin and neomycin, and resistant to ampicillin, etc.

\section{Discussion}

P. mirabilis and $P$. vulgaris are the two well-known species in the genus Proteus. Two other species, $P$. myxofaciens and $P$. penneri are more recent addition to the genus. $P$. penneri was not included in Bergey's Manual of Systematic Bacteriology (Vol. 1, 1984), because it was described after the submission date for the 
chapter on Proteus. However, it has recently been recognized that the genus Proteus is composed of four species $^{4)}$.

In 1981, Hickman et al studied the DNA hybridization groups of $P$. vulgaris and indicated that one group (indole-, salicin-, and esculin-negative) probably represented a new species of Proteus. They did not give the species a scientific name, referring to it instead as $P$. vulgaris biogroup 1 . In addition, there are two other biogroups: P. vulgaris biogroups 2 which is indole-, salicin-, and esculin-positive, and biogroups 3 , which is indole positive, and salicin-, and esculin-negative.

In 1982, the DNA hybridization of the three biogroups of $P$. vulgaris was once again studied by Hickman et al. A highly related group was formed ( 88 to $99 \%$ relatedness at $60^{\circ} \mathrm{C}$ and 67 to $96 \%$ relatedness at $75^{\circ} \mathrm{C}$ ) when DNA from $P$. penneri strain $1808-73$ was labeled and tested against unlabeled DNA from 13 other $P$. penneri strains. The relatedness of unlabeled DNA from the $14 P$. penneri strains to labeled DNA from the type strain of $P$. vulgaris and from biogroups 2 strains was determined. These strains were not related to the $P$. penneri strains at the species level, and strains of biogroups 2 were not highly related to the type strain of $P$. vulgaris. For this reason, Hickman proposed that the strains that had previously been designated $P$. vulgaris biogroups 1 should be elevated to the species level within the genus Proteus. and emphasized that low relatedness by DNA hybridization and phenotypic differences were the main criteria for proposing the new species. The name Proteus penneri was coined to honour John L. Penner, a Canadian microbiologist who made many contributions to the study of the three genera in the tribe Proteus.

The type strain of $P$. penneri was CDC 1803-73 (ATCC33519). The G $+\mathrm{C}$ content was $38 \mathrm{~mol} \%$ (our strain, $38.3 \mathrm{~mol} \%)$.

P. penneri has the following common characteristics of the genus Proteus: positive tests for urea hydrolysis, phenylalanine deaminase, gelatin hydrolysis, $\mathrm{H}_{2} \mathrm{~S}$ production, and swarming on blood agar (our strain, after the third generation of subculturing); and negative results for D-mannose fermentation. The following tests are positive for most strains: methyl red, motility, growth in the presence of $\mathrm{KCN}$, and fermentation of $\mathrm{D}$-galactose, maltose scurose and $\mathrm{D}$-xylose; the others are negative for all or most $P$. penneri strains. Clinical laboratories should suspect $P$. penneri in the case of a Proteus strain that is indole-, esculinand salicin-negative, and resistant to chloramphenical (zone size, $14 \mathrm{~mm}$ ).

The clinical significance of $P$. penneri is unknown, although the 20 strains reported by Hickman et al included 9 isolated from urine, 4 from stool, 1 each from blood, abdominal wound, and respiratory tract, and 4 from unspecified sources. The ecology of this organism and its role in human disease will be substantiated as clinical information is accumulated. The present case involved a patient who had suffered from chronic suppurative otitismedia for eight years. Some inappropriate antimicrobial agents were administered, so that the patient's condition worsened with epidural abscess and otogenic meningitis. Therapy with surgery and effective antibiotics following bacteriological susceptibility testing resulted in rapid resolution of the infection.

\section{References}

1) Hickman, F.W, et al: Identification of Proteus penneri sp., nov., formerly known as Proteus vulgaris biogroup; J. Clin. Microbiol 15(6): 1097, 1982.

2) Krieg, N.R.(ed).: Bergey's Manual of Systematic Bacteriology, Vol. 1. Baltimore: Williams \& Wilkins Co. 491, 1984.

3) Cosenza, B.J., et al.: A new species of Proteus isolated from larvae of the gypsy moth Porthetria dispar. Antonie von laeuwenhoek. J. Microbiol. Serol. 32: 187, 1966.

4) Farma, J.J., III, et al.: Biochemical identification of new species and biogroups of Enterobacteriaceae isolated from clinical specimans. J. Clin. Microbiol. 21(1): 46, 1985.

5) Lennete, E.H.: Manual of Clinical Microbiology, 4th ed. Washington: American Society for Microbiology 271, 1985. 


\section{Proteus penneri による硬膜外膿瘍の一例}

(平成 3 年 7 月 8 日受付)

(平成 3 年 9 月 10 日受理)

症例は17歳男性， 2 週間来持続する頭痛および 高熱, 悪心により入院す.入院時現症は体格中等 度, 栄養良好, 皮膚扣よび眼球結膜に黄㾝を認め ず, 体温 $37.5^{\circ} \mathrm{C}$, 脈拍 $84 /$ 分整, 血圧 $110 / 70 \mathrm{mmHg}$, 聴打診上では異常なく, 腹部所見では肝, 脾触知 せず，その他の異常は認めなかった。神経学的に は左側の不完全顔面神経麻痺を認めた。局所所見 としては, 左乳様突起部位に軽度の腫張を認め, 鼓膜表面に化膿性分泌物を認めた。既往歴に 8 年
来の左化膿性中耳炎を罹患していることより，硬 膜外膿瘍および耳原性髄膜炎を合併した化膿性中 耳炎と診断, 根治的乳様突起切除術を施行した。 硬膜下腔より $150 \mathrm{ml}$ の膿汁を採取, 細菌検査によ りP. penneriを検出, 感受性試験により cotrimoxazole と gentamicin を使用し軽快, 退院し た. P. penneri は P. vularis として分類されてい たが, 1982年 Hickman らにより尿, 糞便より検出 されたがその臨床的意義は不明である。 